\title{
Studi Karakteristik Kualitatif Dan Kuantitatif Kerbau Lumpur Di Kecamatan Kampar
}

\author{
YENDRALIZA \\ Universitas Islam Negeri, Pekanbaru
}

\begin{abstract}
The aim of the present work was to study the physical characteristics of swamp buffalo population in Kampar sub district, Riau province. Thirty buffalos which were distributed in 5 villages (Kampar, Padang Mutung, Pulau Rambai, Pamyasauan, and Batu Belah) were selected by Multi Stage Stratified Cluster Purposive Sampling Method. The selected animals which were consisted of 15 males and 15 females were observed for physical performance and measured for some body parameters. Physical performances observed and body parameters measured included: horn form; color of hair, skin and foot; form of foot and udder; body length, thorax circle, shoulder high, shoulder circle, thorax high and scrotum circle. The quantitative data were tabulated for calculation of means and standard deviation. It was found that about $83,3 \%$ of buffalo population had horn with wider form, 72,3\% hair color of blackish grey, $61,2 \%$ skin color of blackish gray, $100 \%$ foot color of grey, $100 \%$ foot form of well built foot and $100 \%$ udder form of symmetric. The body measurement data reflected that the body development of the buffalo in Kampar closely related to their original population in India.
\end{abstract}

Key Words: Swamp buffalo, physical performances, body measurement

\section{Pendahuluan}

Meningkatnya jumlah penduduk yang disertai dengan kesadaran masyarakat akan pentingnya protein hewani mendorong perubahan konsumsi masyarakat. Hal ini membuat permintaan komoditi hasil peternakan makin meningkat. Namun peningkatan permintaan ini tidak diiringi dengan meningkatnya populasi ternak. Ternak kerbau merupakan penyumbang protein hewani setelah ternak sapi. Di Kabupaten Kampar ternak kerbau merupakan ternak dominan. Ini terlihat dari tingginya jumlah populasi ternak kerbau dibandingkan ternak sapi. Populasi ternak kerbau terbesar di Kabupaten Kampar terdapat di Kecamatan Kampar dengan total populasi 5,345 ekor (BPS, 2004). Namun dari data dinas Peternakan
Riau dalam 3 tahun terakhir terjadi penurunan populasi ternak kerbau dengan laju penurunan sebesar 0,53 $\%$. Namun pemotongan ternak kerbau memperlihatkan peningkatan sebesar $0,17 \%$. Dan jika hal ini tidak diantisipasi maka kelestarian hidup ternak kerbau sebagai ternak andalan di Kabupaten Kampar dan Kecamatan Kampar khususnya akan mengalami kekurangan.

Untuk mengantisipasi kondisi diatas maka Pemerintah Daerah mulai melakukan penyebaran ternak kerbau kepada masyarakat dengan system gaduhan.

Selain itu peningkatan populasi juga membutuhkan data mengenai karakteristik individu (performans) yang terdiri dari karakteristik kualitatif dan karakteristik kuantitatif. Namun sampai sejauh ini data tentang karakteristik ternak kerbau di daerah 
ini belum banyak diketahui, padahal penampilan individu sangat penting artinya karena berkaitan erat dengan keberhasilan pengembangan dan pelestarian ternak kerbau dimasa yang akan datang.

Berdasarkan uraian diatas, maka dilakukan penelitian tentang studi karakteristik sifat kualitatif dan sifat kuantitatif kerbau rawa di Kecamatan Kampar.

\section{Materi Dan Metode Penelitian}

Penelitian ini akan dilaksanakan di Kecamatan Kampar selama 2 bulan mulai Mei 2006 sampai Juli 2006.

Alat yang digunakan dalam penelitian ini adalah :

1. Pita ukur dengan ketelitian 0,01 cm

2. Paralel bar (tongkat ukur) dengan ketelitian $0,01 \mathrm{~cm}$

Dalam penelitian ini akan digunakan 2 macam data. Data primer dan data sekunder sebagai data penunjang. Data primer didapatkan dengan mengukur ternak tersebut dengan menggunakan pita ukur dan parallel bar. Ukuran - ukuran ini digunakan untuk mengestimasi bobot badan dari ternak kerbau yang akan dibedakan menurut tingkatan umur, (Anak (gudel), Dara/muda, dan dewasa) dan jenis kelamin (jantan dan betina). Data sekunder didapatkan dari Dinas Peternakan setempat.

Metode penelitian yang digunakan adalah metode survey dan penilaian langsung di lapangan. Analisa data yang diperoleh dilakukan secara deskriptif. Pengambilan sample dilakukan dengan metode Multi Stage Stratified Cluster Purposive Sampling (Gasperz, 1992)

Penentuan lokasi dan pengambilan sample penelitian dilakukan bertahap dengan urutan sebagai berikut :

a. Daerah yang ada di kecamatan Kampar dikelompokkan berdasarkan kepadatan populasi ternak kerbau dengan cara purposive sampling yaitu berdasarkan ternak kerbau terbanyak dan lokasi terdekat dari Pekanbaru sehingga dari 30 desa yang ada di kecamatan Kampar terpilih 5 desa yaitu desa Kampar, desa Padang Mutung, desa Pulau Rambai, desa Panyasauan, Desa Batu belah dengan populasi kerbau pada masing-masing desa; 135 ekor; 263 ekor; 210 ekor; 42 ekor; 35 ekor. (Kantor Camat Kampar, 2004)

b. Dari setiap desa terpilih, diambil 2 dusun yang mewakili dengan cara purposive sampling yaitu berdasarkan jumlah ternak kerbau terbesar dan wilayah yang mudah terjangkau. Untuk desa Kampar terpilih dusun Pasar dan dusun Sawah, Desa Pulau Rambai terpilih Dusun Pulau Sayak dan Dusun Pulau Kampung, Desa Padang Mutung terpilih Dusun Pulau Tinggi dan Pulau Baru, Desa Panyasauan terpilih Dusun Panyasauan Barat, Desa Batu belah terpilih Dusun 1 saja.

c. Jumlah sampel yang akan diambil pada setiap daerah desa adalah minimal 30 ekor kerbau atau berdasarkan populasi kerbau yang terdiri dari 15 ekor betina dan 15 ekor jantan yang terdiri atas 3 tingkatan umur sehingga jumlah sample yang terkumpul nantinya adalah 150 ekor.

Data karakteristik kualitatif dan kuantitatif yang didapatkan dita- 
bulasikan dan dianalisa dengan cara penjumlahan dan dicari rata - rata serta standar deviasi dengan menggunakan rumus Steel dan Torrie (1985) dan diolah dengan SPSS 10,5

\section{Hasil Dan Pembahasan}

\section{Karakteristik Sifat Kualitatif}

Berdasarkan hasil pengamatan di lapangan, karakteristik sifat kualitatif ternak kerbau baik jantan dan betina dapat dilihat pada Tabel 1 .

Tabel 1, memperlihatkan bahwa bentuk tanduk kerbau secara umum baik jantan maupun betina dapat dibagi dua yaitu menjadi bentuk semi melingkar dan melebar. Namun bentuk melebar lebih dominan $(83,3$ $\%)$ dibandingkan dengan semi melingkar $(16,7 \%)$. Hal ini memperlihatkan bahwa dari fenotip (sifat yang nampak) pada kerbau di Kecamatan Kampar merupakan turunan dari kerbau India yang mempunyai tanduk dominan melebar (Murti, 2000).

Warna bulu kerbau yang dominan adalah abu - abu bercak putih yaitu $72,3 \%$ sedangkan abu-abu hitam hanya $27,7 \%$-nya lagi. Hal ini sejalan dengan hasil penelitian Mc Gregor, 1939 dan Fahimudin, 1975 dalam Murti, 2000) bahwa warna tubuh Kerbau Lumpur Asia rata - rata bewarna abu-abu putih sampai hitam.

Warna kulit yang dominan ditemui adalah abu - abu hitam 61,2 $\%$ sedangkan kebiru - biruan hanya $38,8 \%$. Hampir semua kerbau yang ditemui mempunyai garis putih dileher yang disebut brisket. Warna albino belum pernah ditemui.

Warna kaki yang dominan dijumpai adalah abu - abu yaitu 100
$\%$ dengan bentuk kaki yang tegap. Hal ini memperlihatkan bahwa kerbau lumpur yang ada merupakan tipe kerbau pekerja.

Ambing yang ada pada betina rata-rata tidak berkembang dengan baik tapi semua kerbau betina yang ditemui memiliki ambing yang simetris dengan 4 puting susu. Hal ini memperlihatkan bahwa tipe kerbau lumpur adalah tipe pedaging bukan tipe perah.

\section{Karakteristik Sifat Kuantitatif (ukuran-ukuran Tubuh) ternak Kerbau di Kecamatan Kampar}

Berdasarkan hasil pengamatan dan pengukuran di lapangan maka data sifat kuantitatif ternak kerbau di Kecamatan Kampar dapat dilihat pada Tabel 2.

Dari Tabel 2 diatas terlihat bahwa ukuran - ukuran tubuh ternak jantan lebih panjang dari ukuran ternak betina kecuali pada ternak betina dewasa yang lebih panjang dari ternak jantan dewasa. Panjangnya ukuran ternak jantan dibandingkan ternak betina ini diduga karena fetus jantan lebih aktif menyerap makanan dari induk dibandingkan dengan fetus betina dan adanya pengaruh hormone testosterone pada fetus jantan serta lamanya fetus dalam kandungan. Hal ini sesuai dengan Toelihere (1989) yang menyatakan bahwa jenis kelamin menentukan lama kebuntingan dimana anak jantan akan dikandung lebih lama dari anak betina. Data pengukuran ini tidak jauh beda dengan yang didapatkan oleh Parker, B.A,. (1984) dalam Murti (2000). 
Tabel 1. Data Karakteristik Kualitatif Ternak Kerbau Di 3 Desa Di Kecamatan Kampar.

\begin{tabular}{|c|c|c|c|c|}
\hline Sifat Kualitatif & Jantan & Betina & Jumlah & Persentase (\%) \\
\hline $\begin{array}{l}\text { Bentuk Tanduk: } \\
\text {-Semi Melingkar (menyabit) } \\
\text { - Melebar }\end{array}$ & $\begin{array}{c}5 \\
30\end{array}$ & $\begin{array}{l}10 \\
45\end{array}$ & $\begin{array}{l}15 \\
\frac{75}{90} \\
\end{array}$ & $\begin{array}{l}16,7 \% \\
83,3 \%\end{array}$ \\
\hline $\begin{array}{l}\text { Warna Bulu } \\
\text { - Abu-abu bercak putih } \\
\text { - Abu-abu Hitam }\end{array}$ & $\begin{array}{c}20 \\
5\end{array}$ & $\begin{array}{l}45 \\
20\end{array}$ & $\begin{array}{l}65 \\
\frac{25}{90}\end{array}$ & $\begin{array}{l}27,7 \% \\
72,3 \%\end{array}$ \\
\hline $\begin{array}{l}\text { Warna Kulit } \\
\text { - Kebiru-biruan } \\
\text { - Abu-abu Hitam } \\
\text { - Albino }\end{array}$ & $\begin{array}{l}15 \\
25 \\
-\end{array}$ & $\begin{array}{l}20 \\
30 \\
-\end{array}$ & $\begin{array}{l}35 \\
55 \\
00 \\
90\end{array}$ & $\begin{array}{l}38,8 \% \\
61,2 \%\end{array}$ \\
\hline $\begin{array}{r}\text { Warna Kaki } \\
\text { - Abu-abu }\end{array}$ & 30 & 60 & 90 & $100 \%$ \\
\hline $\begin{array}{l}\text { Bentuk Kaki } \\
\text { - Tegap }\end{array}$ & 30 & 60 & 90 & $100 \%$ \\
\hline $\begin{array}{l}\text { Bentuk Ambing } \\
\text { - Simetris } \\
\text { - Asimetris }\end{array}$ & - & $\begin{array}{c}45 \\
-\end{array}$ & $\begin{array}{l}45 \\
- \\
45\end{array}$ & $100 \%$ \\
\hline
\end{tabular}

Tabel 2. Sifat Kuantitatif (ukuran-ukuran Tubuh) Ternak Kerbau di Kecamatan Kampar (Cm)

\begin{tabular}{lcccccc}
\hline Sifat Kuantitatif & \multicolumn{3}{c}{ Betina } & \multicolumn{3}{c}{ Jantan } \\
\hline $\begin{array}{c}\text { (Ukuran Tubuh) } \\
(\mathrm{cm})\end{array}$ & Gudel & Dara & Dewasa & Gudel & Muda & Dewasa \\
\hline \multicolumn{1}{c}{$\mathrm{N}$} & \multicolumn{1}{c}{20} & 30 & 30 & 10 & 20 & 15 \\
\hline Panjang Badan & $59,82 \pm 0,99$ & $92,08 \pm 0,81$ & $101,86 \pm 5,3$ & $62,7 \pm 0,15$ & $100,1 \pm 0,11$ & $115,96 \pm 0,88$ \\
Tinggi pundak & $68,5 \pm 0,22$ & $122,86 \pm 0,9$ & $106,06 \pm 0,5$ & $72,00 \pm 0,82$ & $100,50 \pm 1,05$ & $124,23 \pm 0,45$ \\
Lingkar Dada & $69,50 \pm 0,88$ & $154,53 \pm 0,7$ & $147,53 \pm 1,5$ & $82,05 \pm 0,12$ & $130,95 \pm 0,82$ & $150,33 \pm 0,23$ \\
Dalam Dada & $17,00 \pm 1,2$ & $33,77 \pm 0,52$ & $36,06 \pm 0,82$ & $20,22 \pm 0,64$ & $35,12 \pm 0,60$ & $37,66 \pm 0,097$ \\
Lebar Dada & $33,25 \pm 1,2$ & $66,34 \pm 0,86$ & $72,13 \pm 0,43$ & $41,05 \pm 0,68$ & $66,30 \pm 0,92$ & $75,77 \pm 0,064$ \\
Lingkar Scrotum & - & - & - & - & $14,96 \pm 0,88$ & $18,77 \pm 22,42$ \\
\hline
\end{tabular}

Keterangan : $n=$ jumlah ternak Kerbau

\section{Kesimpulan Dan Saran}

\section{Kesimpulan :}

1. Sifat kualitatif ternak kerbau di Kecamatan Kampar meliputi 83,3 $\%$ bentuk tanduk melebar, $72,3 \%$ warna bulu abu-abu hitam, $61,2 \%$ warna kulit abu-abu hitam, $100 \%$ warna kaki abu-abu, $100 \%$ bentuk kaki tegap, dan $100 \%$ bentuk ambing simetris.

2. Sifat kuantitatif ternak kerbau di kecamatan Kampar meliputi panjang badan, tinggi pundak, lingkar dada, dalam dada, lebar dada dan berat badan serta lingkar scrotum untuk pejantan memeprlihatkan bahwa pertumbuhan ternak ker- 
bau di Kecamatan Kampar cukup baik karena data pengukuran ini tidak jauh berbeda dengan data yang didapatkan oleh Parker, B.A.. (1984) dalam Murti (2000) di berbagai daerah di India.

\section{Saran}

Untuk melihat perkembangan dan laju pertumbuhan ternak kerbau di Kecamatan Kampar perlu diadakan penelitian lanjutan dengan perlakuan manajemen yang berbeda dari sekarang. Data ternak kerbau di kecamatan Kampar bisa dijadikan referensi untuk pengembangan pembangunan peternakan kedepan.

\section{Daftar Pustaka}

Anang, A. 1992. Beberapa Sifat Kualitatif Dan Kuantitatif Domba Periangan Jantan Tipe Adu. Jurnal of Padjadjaran Unervesity. No.1 vol. X : hal. $62-66$.

Dinas Peternakan Provinsi Riau. 2003. Statistik Peternakan Provinsi Riau.

Djagra, I.B. 1994. Pertumbuhan sapi bali : Sebuah analisis berdasarkan dimensi tubuh. Majalah Ilmiah UNUD Tahun XXI No.39, Januari. Hal. 73 82

Gasperz, V. 1992. Teknik Analisis Dalam Penelitian Percobaan. Penerbit Tarsito, Bandung.

Hardjosubroto, W. 1994. Aplikasi Pemuliabiakan Ternak Di

Penerbit PT. Gramedia Pustaka Utama. Jakarta.

Tulloh. N.M and J.H.G.Holmes. 1992. Buffalo Production. School of Agriculture and Forestry, The University of Melbourne. Auatralia.
Lapangan. Penerbit Gramedia Widiasarana Indonesia, Jakarta.

Huitema, H. 1986. Peternakan Di Daerah Tropis Arti Ekonomi Dan Kemampuannya. Penerbit PT. Gramedia dan Yayasan Obor Indonesia, Jakarta.

Ilyas, A.Z. 1995. Pedoman Pengembangan Dan Perbaikan Ternak Kerbau Diindonesia, Dirjen Peternakan.

Kinghorn, B. 1992. Principles of estimated breeding value. Dalam Hammond, k.H.U. Garsser. C.A. Mc. Donald (Ed). Animal breeding the modern approach. Post graduate foundation in veterinary science. University of Sidney.

Murti, W.T. 2000. Ilmu Ternak Kerbau. UGM Press. Yogyakarta.

Nazir. M. 2003. Metode Penelitian. Penerbit Ghalia Indonesia. Jakarta.

Noor, R.R. 1986. Genetika Ternak. Cetakan I.PT. Penebar Swadaya, Anggota IKAPI, Jakarta.

Singarimbun, M dan S. Effendi. 1989. Metode Penelitian Survey. LP3ES. Jogjakarta.

Steel, R.G.D and J.H.Torrie. 1993. Prinsip dan Prosedur Statistika Suatu Pendekatan Biometric.

Warwick, E.J dan J.E. leagates. 1986. Breeding and Improvement of Farm Animal. TMH Edition. Tata Mc Graw Hill Publishing Co. Ltd., New Delhi. 
W. ross Cockrill. 1974. The Yatim, W. 1986. Genetika. Penerbit Husbandry and Health of the Tarsito, Bandung.

Domestic Buffalo. FAO. Roma

Alamat Korespondensi: Yendraliza, S.Pt, M.P

Universitas Islam Negeri Pekanbaru, Riau

Jl. Datuk Laksamana NO. 14 Gobah

Pekanbaru TELP. 0761860507

Diterima: 14 Agustus 2007, Disetujui: 4 September 2007 